Kritische Bibliografie

\title{
VERZET EN TRANSCENDENTAAL EMPIRISME
}

\author{
Helena De Preester
}

Catherine Malabou, Wat te doen met ons brein?, uit het Fr. vert. d. Jeanne Holierhoek, Amsterdam, Boom, 201 1, 144 pp., € 19,95 ISBN 9789461054951

Het absolute denken is voor mij niet helderder dan mijn eindige geest, want alleen door deze ben ik in staat tot het denken daarvan.

(Merleau-Ponty, 2009 [1945] : 522)

\section{Introductie: neuronen en verzet}

Velen weten dat Malabou haar doctoraat in de wijsbegeerte behaalde bij Jacques Derrida, en dat de filosofie van Hegel, de psychoanalyse en de neurowetenschappen de grote punten zijn waartussen haar denken als postdeconstructie-filosofe zich beweegt. Deze denklijnen kruisen op het concept van 'plasticiteit' en zorgen in Wat te doen met ons brein? voor een kritische benadering van het fenomeen 'flexibiliteit'. De reikwijdte van haar denken en van haar wijsgerige agenda wordt duidelijk in de spanning, maar ook de speelruimte die ze traceert tussen 'plasticiteit' en 'flexibiliteit'. Deze ruimte tussen beide zorgt volgens Malabou voor een mogelijkheid tot verzet en rebellie: het neurale subject is inderdaad plooibaar en vormbaar, maar dient zijn brein ook 'in eigen handen te nemen' en zich te verzetten tegen een laatkapitalistische ideologie die het subject reduceert tot een oneindig flexibel gegeven dat voortdurend aanpasbaar is aan de eisen van het laatkapitalistische systeem. Plasticiteit verwijst immers niet enkel naar het ontvangen van vorm, maar ook naar het geven van vorm.

Ik hoorde Catherine Malabou voor het eerst spreken op het Forum voor Europese Filosofie, tijdens de $49^{\text {st }}$ jaarlijkse bijeenkomst van de Society for Phenomenology and Existential Philosophy (SPEP) in oktober 2009 in Washington DC. De Engelse vertaling van haar boek Que faire de notre cerveau (2004) was toen precies een jaar uit, en voorzien van een voorwoord van neuroloog en neurofysioloog Marc Jeannerod, die vorig jaar overleed. De hamvraag tijdens haar lezing was of de plasticiteit van het brein, en dus ook van het subject, zich kan verzetten tegen de flexibiliteit die het kapitalisme ervan vraagt. Ze zette daarbij helder uiteen dat ze inderdaad uit is op een kritiek van de 'neurale ideologie'. Elke visie op het brein is volgens haar immers 
onvermijdelijk ideologisch. Dat komt omdat de intussen ruim aanvaarde continuiteit tussen het neurale niveau en het niveau van het mentale leven een filosofische stap inhoudt, en geen strikt wetenschappelijk postulaat is. Het is in die filosofische stap, die door veel neurowetenschappers wordt genomen, dat de ideologie zich gaat nestelen. Laat ik daarom maar meteen zeggen dat de achterflap van de Nederlandse vertaling Malabous werk enigszins misleidend aankondigt. Malabou valt niet de neurowetenschappen en hun objectiviteit aan. Er is volgens haar niets 'schijnbaars' aan de objectiviteit van de neurowetenschappen. Ook plaatst ze de 'feiten' over onze hersenen niet tussen aanhalingstekens. We hebben dan ook geen reden om kritisch-naief de resultaten uit de breinwetenschappen van de hand te wijzen. Het is eerder bij de overgang tussen brain en mind dat we op onze hoede moeten zijn aangezien daar ruimte opengaat voor interpretatie, positie-inname en ideologie. Malabou zelf doet dat niet minder dan iemand als bijvoorbeeld Antonio Damasio, die ze in haar boek bekritiseert. Toch verschilt ze daarin van hem dat ze bewust omgaat met deze ideologische opvulling in het overgangsgebied tussen brein en geest, en dat doet vanuit een boeiende filosofische hoek. Net zoals Damasio doet ze daarbij een beroep op resultaten uit de breinwetenschappen. Malabou verklaart zich in de grond dan ook eens met het heersende neurodiscours, ze verdedigt bovendien het objectiverende project van de neurowetenschappen. Daarom pleit ze voor beter geïnformeerde burgers, die hun onverschilligheid afleggen tegenover wat er vandaag de dag gebeurt in de neurowetenschappen en de cognitieve wetenschappen. De breinwetenschappen dragen immers een revolutionair potentieel in zich, en het is zaak dit strategisch op zich te nemen vóor dat onmogelijk wordt gemaakt doordat de inzichten ervan worden gerecupereerd door het neoliberale, kapitalistische discours.

Malabous appreciatie van de neurowetenschappen is zeker geëvolueerd. Op een vraag uit het publiek tijdens de SPEP-conferentie gaf ze toe wel degelijk van opvatting te zijn veranderd, bijvoorbeeld wat het neuraal darwinisme van Gerald Edelman' betreft. In tegenstelling tot haar eerdere afwijzing, beschouwt ze neuraal darwinisme nu als een theorie aangaande vrijheid - geen inherent kapitalistisch discours waarin enkel survival of the fittest van tel is.

\section{Een ideologisch scherm}

De strijd om bewustwording van de leek stopt echter niet bij het aan de man brengen van een aantal neurowetenschappelijke inzichten, iets wat ze vooral in het eerste van de drie delen van haar boek doet. De strijd begint daar pas. De recente ontwikkelingen in de neurowetenschappen zouden ons moeten afhelpen van de oude en niet langer adequate opvatting dat de hersenen zoiets als een gecentreerd en centraliserend programma vormen (cf. de computermetafoor) waarin geen ruimte is voor wijzigingen en voor het 'andere' - een ooit populaire 
maar intussen verouderde visie die nog sterk leeft onder wie zich niet informeerde over recentere ontwikkelingen. Deze nieuwe inzichten zouden het ons mogelijk moeten maken in verzet te komen tegen de huidige gang van zaken in de wereld, of de heersende wereldorde. Dat is een verrassende stap, en het is precies in die stap dat de kracht schuilt van het discours van Malabou.

Helaas is die stap van recente neurowetenschappelijke inzichten naar verzet en vrijheid niet zo gemakkelijk te nemen. Malabou ontwaart immers een 'ideologisch scherm' (67) dat ons weerhoudt van de mogelijkheid tot verzet. Dat heeft alles te maken met een parallellie tussen het neurale en het politieke, tussen het neurowetenschappelijke discours en het heersende managementsdiscours. Net zoals de hersenen, berust ook de neoliberale ideologie op een spreiding van de centra en een versoepeling van de hiërarchie. Malabou legt dat uit door erop te wijzen dat begrippen zoals netwerken, de onophoudelijke eis tot verplaatsing en de voortdurende eis tot aanpassing centraal staan in beide domeinen, het cerebrale en het sociaal-economische. Het neurale functioneren lijkt zo wel de natuur van het sociale te zijn. Wie zijn netwerken niet onderhoudt, zich niet aanpast en weigert op verschillende gebieden competent en inzetbaar te zijn, valt eruit - biologisch én economisch-sociaal, 'breinsgewijs' en maatschappelijk. Dat is problematisch: " $[\ldots]$ in ideologisch opzicht is het nog niet mogelijk om een strikt onderscheid te maken tussen de voor het 'grote publiek' toegankelijke neurowetenschappelijke analyses en de managementliteratuur [...]" (85). Dat komt niet doordat de 'feiten' van de neurowetenschappen niet zouden kloppen. Het komt wel, en dat zien we in het derde en laatste deel, doordat de zogenaamde spiegeling tussen hersenen en wereld een ideologische spiegeling is, of beter, doordat het bewustzijn van deze spiegeling tot nog toe ontbreekt en daarom niet kan worden ingezet voor "politieke inzichten die een emancipatorisch effect zullen hebben" (87). Malabou 'ontmaskert' dus geen verondersteld ideologisch gehalte van het strikt neurowetenschappelijke onderzoek als zodanig. Ze roept wel op tot iets wat ze slechts erg complex kan verwoorden, doordat de koppeling die zij maakt tussen neurowetenschappen, kapitalisme en politiek verzet erg nieuw is.

Vatten we even de opzet samen. Het hoopvolle uitgangspunt van Malabou is dat "[D]e vooruitgang in de neurowetenschappen [...] op een bepaalde manier de politieke emancipatie van de hersenen mogelijk [heeft] gemaakt" (88). Het probleem wordt echter gevormd door de ambivalentie die in de zaak schuilt, aangezien de plasticiteit van de hersenen wordt weerspiegeld (ook bij een aantal neurowetenschappers) door een discours dat flexibiliteit en dus volgzaamheid en gehoorzaamheid vooropstelt. Het is hier dat de neoliberale ideologie het revolutionaire potentieel van het inzicht in de plasticiteit van de hersenen kaapt en de mogelijkheden tot plastisch verzet smoort. ${ }^{2}$ 


\section{Plasticiteit en kneedbaarheid: de biologische achtergrond}

Malabou presenteert een aantal inzichten in verband met de plasticiteit van de hersenen. Daarbij wordt uitgebreid gebruik gemaakt van het werk van neurowetenschappers Jean-Pierre Changeux ${ }^{3}$ en Marc Jeannerod. Changeux staat bekend om de verdediging van de stelling dat niet instructie, maar selectie centraal staat in levensprocessen. Drie soorten plasticiteit van de hersenen worden onderscheiden. Ten eerste de totstandkoming van neurale verbindingen tijdens de neurogenese, een proces van hersenontwikkeling dat (epi)genetisch bepaald is en nog 20 'n vijftien jaar na de geboorte verdergaat. Bij deze vorm van plasticiteit worden de hersenen gevormd, op een bepaalde manier. Tijdens de neurogenese komen verbindingen niet enkel tot stand door groei, maar in een vroege fase ook door het normale verschijnsel van celdood, waarbij nutteloze verbindingen geëlimineerd worden. Het gebruik van de term 'plasticiteit' is hier duidelijk geïnspireerd door de plastische kunsten. De metafoor van de beeldhouwer die met een beitel overbodig materiaal weghaalt om een welbepaalde vorm te bekomen, wijst erop dat plasticiteit zich inderdaad onderscheidt van flexibiliteit. Flexibiliteit wijst op het niet-definitieve van een vorm, waarbij het materiaal elastisch terugspringt en opnieuw een (andere) vorm kan aannemen. Het plastische proces is ook vormend, in de zin dat de verbindingen die tot stand komen mee de identiteit van het subject bepalen. Bij een tweede vorm van plasticiteit is het vooral de interactie met de omgeving, en dus ervaring, die leidt tot onder meer het aanpassen van synaptische effectiviteit. Onze hersenen worden gemodelleerd door onze eigen activiteit, door onze interactie met de buitenwereld. In die zin weerspiegelen de hersenen van het individu zijn of haar individuele en particuliere geschiedenis. Een derde vorm van plasticiteit is het herstel van de hersenen na beschadiging. Hierbij kan het gaan om werkelijke neurale vernieuwing, of om het overnemen van functies van beschadigde gebieden door nog intacte gebieden (reorganisatie). Plasticiteit wijst dus zowel op het definitieve als op het kneedbare karakter van de vorm van het brein. Hoewel niet elastisch, is ons brein het resultaat van een geschiedenis die we zelf mee in handen hebben, zodat het brein zijn biologische bestemmingen kan 'ombuigen' of bijsturen.

\section{Theoretische spleten en ideologie}

Dat neurale verbindingen soepel zijn en niet gehoorzamen aan een gecentraliseerd en strikt hiërarchisch systeem, lijkt sterk op de huidige, soepele organisatie van politiek en economie, waarin het centrum lijkt te zijn verdwenen en commandovormen in een netwerk gespreid liggen. Het is in het tweede deel dat Malabou ons uitgebreid wijst op de gelijkenissen tussen de plasticiteit van de hersenen en de flexibiliteit die van het subject wordt gevraagd in het huidige 
neoliberale systeem. Gecentraliseerde autoriteit is vervangen door controle door middel van zelforganisatie, lees: zelfcontrole. Multi-inzetbaarheid, beschikbaarheid, mobiliteit, onthechting van vaste taken en vaste plaatsen, de bereidheid om oude banden op te geven en nieuwe aan te knopen zijn dé kenmerken van waardevolle personeelsleden en arbeidskrachten. Het lijkt alsof het functioneren van de hersenen de natuur is van het sociaal-economischpolitieke bestel. Met andere woorden: neurale plasticiteit lijkt een biologische rechtvaardiging te zijn voor de eis tot flexibiliteit. Het is in het derde en laatste deel dat Malabou aankomt bij het scharnierpunt en de eigenlijke kritiek. Daar waagt ze zich aan de moeilijke en abstracte evenwichtsoefening om zowel het materialistisch-reductionistisch gezichtspunt van de neurowetenschappen te steunen als een kritiek te leveren op een visie die daar erg vaak mee samengaat, maar er volgens haar niet noodzakelijk uit volgt. Die visie houdt in dat er een continue overgang is tussen het niveau van het neurale en het mentale. Zonder een dualistisch model te willen verkondigen, pleit zij voor de erkenning van verschillende niveaus van organisatie en werking, waarbij de mogelijkheid tot negatie en breuk tussen de niveaus behouden blijft. Malabou gaat hier wat onnauwkeurig te werk, want erg 'hard' lijkt haar materialistischreductionistische gezichtspunt niet te zijn. Overigens lijkt ze neurowetenschappers wel erg snel te beschouwen als per definitie materialistische reductionisten. Iemand als Edelman (1993) bijvoorbeeld is veel genuanceerder in zijn afwijzing van een reductionisme waarvan hij de wortels ziet in de Verlichting en de verzuchting naar een volledige wetenschap. Het lijkt erop dat Malabous verdediging van een materialistisch reductionisme vooral een stok achter de deur is tegen het mogelijke verwijt dat haar erkenning van verschillende niveaus van organisatie naar een lichaam-geestdualisme neigt.

Duidelijk hegeliaans geïnspireerd, zijn de verwoordingen hier veel moeizamer en bestaat het gevaar erin dat een lezer die weinig vertrouwd is met Hegel gaat afhaken. Malabou noemt het reductionisme tegelijk het sterkste en het zwakste punt van het neurowetenschappelijke discours. Hoewel op het eerste gezicht een krachtig instrument om dat discours te analyseren, is de vooronderstelling dat alle breinwetenschappers reductionistisch zijn niet gerechtvaardigd. Waar haar analyse wel vruchten afwerpt, is waar ze focust op twee hedendaagse en vooraanstaande neurowetenschappers: Joseph Ledoux en Antonio Damasio. Deze laatste is wellicht beter bekend bij het Nederlandstalige publiek door de Nederlandse vertalingen van zijn populariserend werk. ${ }^{4}$ Malabou focust op de trapsgewijze totstandkoming van het 'zelf' in de theorie van Damasio, en wil komen tot een kritische confrontatie tussen flexibiliteit en plasticiteit om zo te kunnen onderscheiden wat in de nieuwe definitie van het 'zelf' aan wezenlijk bevrijdends of onderwerpends schuilt. Malabou heeft de gewoonte om veel en vaak ook uitgebreid te citeren, we krijgen dus veel Damasio voorgeschoteld. Uiteindelijk is het uitgebreide citeren niet nodig om 
duidelijk te maken dat de fascinerende analyses in populariserend werk van onderzoekers als Damasio op vele punten tekort schieten.

Op welke punten? Malabou situeert de gebreken vooral daar waar theoretische 'spleten' haast onopgemerkt passeren terwijl de schrijver, Damasio, toch overschakelt van een beschrijvend (objectieve feiten omtrent de hersenen) naar een interpreterend discours. Het is gevaarlijk als de lezer deze overgang en de bijhorende 'spleet' niet opmerkt, want het is daar dat een kritische houding nuttig of zelfs noodzakelijk is. Een onopgemerkte spleet is immers al te vaak opgevuld met 'niets dan brute en naieve ideologie' (101). Een ander voorbeeld is de soms snel gemaakte overgang van neuraal darwinisme naar mentaal of psychologisch darwinisme, en het moet gezegd dat filosofen die zich vandaag bezighouden met het brein en de mind zich soms al te bereidwillig lenen tot een onopgemerkt mee oversteken van de theoretische spleet. In de lijn van Sigmund Freuds project van een metapsychologie, pleit Malabou daarom voor een metaneurobiologische dimensie die de kritische taak wel op zich neemt, zodat men minstens vermijdt om onopgemerkt een ideologische koers te gaan varen. I k laat de lezer zelf het plezier om Malabous kritiek op de 'maximaal harmonieuze en maximaal rijpe persoonlijkheden' (Damasio, geciteerd in Malabou, 2011: 104) te ontdekken.

Samengevat, het is bij de overgang van het neurale naar het mentale, van het biologische naar het culturele, historische en dus ook politieke en maatschappelijke, dat we waakzaam moeten zijn. In die overgang kunnen we de kansen tot verzet aangrijpen en eventueel concretiseren, maar ook kwijtspelen.

\section{Strategisch verzet en een vierde soort plasticiteit}

Hoofdzaak is voor Malabou dat het bevrijdende potentieel van de hersenen, door de neurowetenschappen aan het licht gebracht, ons niet bevrijd hebben. De bevrijde (want door plasticiteit gekenmerkte hersenen) hebben niet geleid tot een bevrijd subject. Net daarom acht ze haar pleidooi voor een verzet tegen de flexibiliteit nodig, "tegen de ideologische norm die, bewust of onbewust, verpakt zit in het reductionistische discours dat het neurale proces modelleert en naturaliseert om een bepaalde vorm van maatschappelijk en politiek functioneren te rechtvaardigen" (109). In het kielzog van deze oproep tot verzet formuleert ze een strategische piste, dat wil zeggen geen alternatief discours dat zich van buiten uit verzet tegen het flexibiliseringsdiscours, maar een verzet van binnen uit dat strategische vormen van verzet in het systeem incorporeert. Strategisch verzet betekent voor Malabou een pleidooi voor de erkenning van een vierde soort plasticiteit, door neurowetenschappers niet in rekening gebracht. Deze vierde soort plasticiteit is zelfvorming en de identiteit die daaruit voortkomt, iets wat volgens Malabou gebeurt in een dialectisch proces. We krijgen hier erg boeiende aanzetten tot een theorie over de subjectwording van uitgesproken 
hegeliaanse snit. Centraal in haar bijdrage staat de idee dat elke vorm van zijn, elke identiteit, haar tegenspraak, haar negatie in zich draagt. Deze negatie, of dit verzet, maakt transformatie mogelijk. Er is een voortdurende spanning tussen behouden en transformeren die mogelijk is op basis van plasticiteit. Hier ligt ook het grote verschil met de flexibiliteit, die deze spanning niet in zich draagt en daarom niet creatief is, maar louter reproductief en normerend.

De overgang van het neurale naar het mentale wordt ook door een wederzijds conflict gekenmerkt. Deze overgang van de ene orde naar de andere is slechts mogelijk op basis van wat Malabou een 'ontologische explosie' noemt. In tegenstelling tot het discours van iemand als Damasio, erkent Malabou het "geweld van een kloof die alle continuilteit [d.w.z. tussen verschillende ordes] beëindigt" (116). De biologische matrix wordt daarbij niet verloochend of vergeten maar (hegeliaans) opgeheven. Daardoor wordt ook een stap richting vrijheid gewonnen, want de opheffing is er ook een van natuur naar vrijheid. De overgang van een zelfregulerende structuur (een 'proto-zelf' in Damasio's termen) die gevormd en gekneed wordt door de omgeving naar een structuur die haar eigen organisatie kan opleggen voltrekt zich dus niet zonder horten en stoten, niet 'zonder breuk of kloof' (119). Het is die 'ontologische explosie' die de ideologische spiegeling tussen het biologische en het sociaal-politiekeconomische vernietigt.

Uiteindelijk leidt dit tot een oproep om te weigeren "het flexibele individu te zijn dat een voortdurende zelfcontrole combineert met het vermogen om mee te buigen met de stromen, overdrachten en uitwisselingen, uit angst voor de explosie." (123). Malabou verbindt aan de term 'plasticiteit' immers ook het beeld van de kneedbom (plastic bomb) en de explosie, maar echt overtuigend werkt dit beeld niet. In elk geval roept ze op tot niet-terroristische explosies, tot woede als tegenreactie op de cultuur van gedweeheid en beminnelijkheid 'terwijl we toch in een voortdurende staat van oorlog leven' (124).

\section{Valstrikken: naturalisering en transcendentalisme}

Intussen zijn de neurowetenschappen niet enkel zaak van de gewone burger. Ze dringen ook door in de humane wetenschappen. Daar wordt vaak afwijzend gereageerd op deze indringing. Volgens Malabou hoeft dit niet, en zal het krampachtig ophouden van de scheiding tussen het symbolische en het materiële ons niet redden, integendeel. Ze pleit ook hier in de eerste plaats voor een kritische verhouding tot de breinwetenschappen, en opnieuw niet in de laatste plaats door neurowetenschappers zelf. Een aan de Nederlandse vertaling toegevoegde nabespreking door Malabou zelf, geschreven zeven jaar na het verschijnen van de originele Franse versie, brengt een aantal nuances aan in de boodschap van haar boek. Zo blijkt dat de ontologische explosie niet altijd even duidelijk vast te stellen is. Plasticiteit en flexibiliteit worden dan ook niet als 
alternatieven voorgesteld die probleemloos uit elkaar zouden kunnen worden gehouden. De verhouding tussen beide is eerder ambigu, en dat verklaart ook een zekere ambiguiiteit in haar boek: "Het lijkt onmogelijk om te bepalen of de plasticiteit de subjectieve vertaling is van het nieuwe kapitalisme of dat ze staat voor de contradictie die ze ermee vormt. Of ze de nieuwe mascotte is van de geglobaliseerde economie - geen denkende subjecten meer, maar volgzame hersenen - of dat ze juist, door haar vermogen tot vorming en explosie tegelijk, een ongekende mogelijkheid tot verzet opent." (135) Malabou lijkt dus wel degelijk een stap terug te zetten: we weten niet goed of het neurobiologische discours, dominant in de media en intussen ook in de menswetenschappen, de objectieve bondgenoot is van de globalisering of integendeel ook de mogelijkheid biedt om de tegenaanval in te zetten. Het voorheen duidelijk uitgewerkte idee dat flexibiliteit de ideologische transformatie van plasticiteit is, blijkt dus minder evident te zijn dan eerst gedacht. Waar plasticiteit eerst 'goed' en flexibiliteit 'slecht' was, lijkt de zaak nu complexer te worden. Het nieuwe management is evengoed de objectieve versie van de plastische structuur van het zenuwstelsel. Dat wil zeggen dat neurale plasticiteit de naturalisering van het kapitalisme is, en dus een subjectieve vertaling van het hedendaagse kapitalisme. De problematiek wordt omgedraaid: plasticiteit is mogelijks de vertaling van het kapitalisme, niet omgekeerd. ${ }^{5}$

De ambivalentie kadert echter binnen een veel grotere opdracht die Malabou wel te berde brengt, maar die ze niet in verband brengt met de ambivalentie. Deze grotere opdracht bestaat erin een weg te zoeken tussen het natuurlijke en het transcendentale. Dat wil zeggen dat we volgens Malabou een middenweg zouden moeten kunnen vinden tussen het geloof in een volledige naturalisering van het kenvermogen enerzijds, en het geloof dat het kenvermogen absoluut niet te naturaliseren valt anderzijds. Overhellen naar één van beide kanten is volgens Malabou een theoretische valstrik. Waaruit kan een middenweg bestaan? Precies uit, bijvoorbeeld, het filosofische doordenken van het fenomeen van plasticiteit. Toch blijkt dat niet zo eenvoudig te zijn, getuige de nabespreking door Malabou zelf. Ook de tussenweg blijkt zijn eigen valstrikken te hebben. Het loont dus zeker de moeite om deze tussenruimte tussen naturalisme en transcendentalisme van dichterbij te bekijken.

Zoals gezegd situeert het denken van Malabou zich tussen drie punten: het hegeliaanse denken, de psychoanalyse en de neurowetenschappen. Minder bekend is Malabous duidelijke interesse voor de fenomenologie en het lichaam, die onvermeld blijven in haar boek Wat te doen met ons brein? Nochtans was ze in 2010 bijvoorbeeld te gast op het $28^{\text {ste }}$ Symposium voor Fenomenologie, Cognitie en Neurowetenschappen (aan de Duquesne University) met een lezing over Maurice Merleau-Ponty, fantoomledematen en anosognosie. Ze was daar in het opvallende gezelschap van hedendaagse fenomenologen zoals Shaun Gallagher, Evan Thompson en Dan Zahavi, alle drie denkers die zich onder meer 
bezighouden met het probleem van de naturalisering van de fenomenologie (in husserliaanse, niet in hegeliaanse zin). Het project van de naturalisering van de fenomenologie houdt in dat men poogt om de fenomenologie en de empirische wetenschappen te integreren. In het algemeen kan het 'naturaliseren' van de fenomenologie gedefinieerd worden als het integreren van de inzichten van de fenomenologie in een verklarend kader, waarin elke aanvaardbare eigenschap een continuïteit vertoont met eigenschappen die aanvaard zijn door de natuurwetenschappen (in ruime zin, en dus in tegenstelling tot de sociale wetenschappen). ${ }^{6}$ Het heikele van de zaak is dat Edmund Husserl zijn fenomenologie ontwikkeld heeft in een volgehouden reactie tegen naturalistische interpretaties, dat wil zeggen tegen interpretaties binnen het kader van de natuurwetenschappen, de verklarende, empirische psychologie in het bijzonder. De fenomenologie kan onder meer worden gekarakteriseerd als een doorgedreven beschouwing van de subjectieve ervaring, wat onmiddellijk de kloof tussen de objectiviteit van de cognitieve wetenschappen en de breinwetenschappen enerzijds en de fenomenologische aandacht voor het mentale en de subjectiviteit van de ervaring anderzijds, duidelijk maakt. Ondanks Husserls verzet tegen naturalisering, meent men toch een naturalistisch perspectief in te kunnen nemen met betrekking tot de ervaring, zonder de inzichten van de fenomenologie daarbij te verliezen. Malabou gelooft echter niet in een volledige naturalisering, wat eigenlijk aantoont dat haar reductionistisch materialisme eerder oppervlakkig is.

Anderzijds verdedigt ze evenmin een anti-naturalisering, aangezien ze ook de extreme positie van een doorgedreven transcendentalisme wil vermijden. Het cruciale verschil tussen naturaliseringsprojecten en de transcendentale fenomenologie is dat deze laatste het bewustzijn niet als een deel van de wereld, maar als de bron (de oerregio) ervan beschouwt. ${ }^{7}$ Uiteraard heeft een dergelijk uitgangspunt bijzonder sterke idealistische trekken. De gehele wereld, inclusief ikzelf als een psychofysisch organisme, zou zijn bron vinden in het transcendentale bewustzijn. Het transcendentale bewustzijn is dan de actieve pool die de wereld constitueert. ${ }^{8}$

Malabou kiest duidelijk niet voor deze piste. Ook de subjectieve ervaring is geworteld in het menselijke brein en lichaam en dus verankerd in de materiële wereld. Niet het bewustzijn is de bron van de wereld, maar de wereld is de bron van het bewustzijn. Dat houdt echter niet in dat ze ook een vorm van determinisme aanvaardt. Het bewaren van de actieve karakteristieken van het mentale, uitvergroot in transcendentale filosofieën, is volgens haar best mogelijk in de tussenpositie die ze zoekt. Het natuurlijke (lichaam, brein) aanvaarden betekent niet noodzakelijk de vrijheid opgeven die schuilt in het transcendentale gezichtspunt. Dat is echter een bijzonder moeilijke oefening waarop de fenomenologie haar tanden stuk heeft gebeten. Het is immers niet zo dat de fenomenologie alleen maar een transcendentalisme inhoudt. Een aandachtige 
lezer van zowel Husserl als Merleau-Ponty kan vaststellen dat de actieve pool van het bewustzijn of het mentale leven in de fenomenologie in een spanningsvolle verhouding staat tot het lichaam. Dat heeft alles te maken met de bij Husserl centrale maar vaak uit het oog verloren idee dat het transcendentale ego niet enkel de wereld constitueert en in die zin géén deel is van de wereld, maar anderzijds zichzelf ook in die wereld invoegt. Het transcendentale ego objectiveert met andere woorden ook zichzelf in de wereld. Deze hegeliaans aandoende operatie is het verkennen waard, zeker voor iemand die de aansluiting met de neurowetenschappen zoekt.

\section{De 'verwereldlijking' van het transcendentale}

Husserl is geen filosoof van het lichaam; hij is een filosoof van het bewustzijn. In zijn poging om de rede te funderen ontdekt hij echter afhankelijkheden van andere types van constitutie die de loutere constitutie door het bewustzijn te buiten gaan. Hij ontdekt namelijk het lichaam als constituerende instantie. ${ }^{9}$ Het lichaam is binnen Husserls optie evenwel zelf geen bewustzijn. Niettemin is een ding eerst gegeven aan het lichaam, en niet aan het zuivere bewustzijn, dat 'middels' het lichaam gelokaliseerd is. Husserl gebruikt de term Mundanisierung of Verweltlichung om dit proces te beschrijven. Evengoed had hij de termen 'psychologisering', of 'naturalisering', van het transcendentale kunnen gebruiken. De verwereldlijking van het zuivere, transcendentale ik (of de aanwezigheid van het transcendentale ego in de empirische wereld) laat de wereld zelf echter niet onberoerd. De verwereldlijking of de naturalisering gaat samen met een complementair proces in de wereld, dat in de eerste plaats gepaard gaat met de bezieling van het lichaam, dat nu een bezield lijf wordt (Merleau-Ponty's latere corps-sujet). Met andere woorden, Husserl beschrijft zeer mooi wat een tussenweg tussen het transcendentale en het louter natuurlijke zou kunnen inhouden. Bovendien beschrijft hij ook de complexiteit en hier en daar de onoverkomelijke obstakels die met deze tweevoudige operatie gepaard gaan. De verdinglijking van het zuivere ego in het lichaam, en de bezieling van het lichaam constitueren de dimensie van het psychische (of het mentale, zoals we nu zouden zeggen).

Het transcendentalisme van Husserl is dus nooit zuiver geweest. Zelfs de husserliaanse fenomenologie verkent uitgebreid de door Malabou nagestreefde tussenruimte tussen het natuurlijke en het transcendentale, en probeert aan beide recht te doen. Dat betekent dat we zijn fenomenologie via twee wegen kunnen binnengaan: die van het transcendentale bewustzijn, of die van het bezielde lijf (het psychofysische wezen). Vanuit het standpunt van het transcendentale ego wordt het lichaam als een materiële realiteit beschouwd. Het 'is' er in de modus van het 'tegenover' het bewustzijn. Op die manier bevindt de belichaamde subjectiviteit zich in de causale nexus van de natuur: het is de plaats waar de 
subjectiviteit is genaturaliseerd. Het zuivere bewustzijn (het transcendentale ego) daarentegen kan niet worden genaturaliseerd. Husserl heeft het echter ook over de ziel, die volgens hem wel real is, dat wil zeggen empirisch, deel van de werkelijke wereld, maar toch geen substantie heeft. De ziel is real wegens haar afhankelijkheid van het lichamelijk-natuurlijke. Maar, en hier komen we duidelijk in het vaarwater van Malabou terecht, de ziel is niet enkel van iets externs afhankelijk. Het is hier dat zich een ruimte opent die biologische afhankelijkheden erkent, maar die tegelijk wars is van determinisme. De ziel, hoewel real, heeft geen substantie. Ze is een flux en heeft als flux noodzakelijk een geschiedenis. De veranderbaarheid van een ding is volledig extern bepaald dingen zijn geschiedenisloos. Voor de ziel is het verleden aanwezig, de ziel is geconditioneerd door haar geschiedenis. De ziel is een flux, geen substantie die een flux draagt. "That the soul has a history means that the soul is an ongoing modification of its own past; unlike the thing, it is not something that endures in time, or a modification in time, but is, rather, the very presence of the unfolding of a history." ${ }^{10}$ De realiteit van de ziel is dus een historische realiteit. Hier zijn we weer aanbeland bij Malabous vertrekpunt, waar ze Marx' visie dat de mens zijn eigen geschiedenis maakt (maar niet weet dat hij dat doet), toepast op het brein. Plasticiteit en het vermogen om een geschiedenis te hebben gaan hand in hand, tussen rigide determinisme en absoluut transcendentalisme in.

De oproep en de oefening van Malabou kaderen heel duidelijk binnen diezelfde spanningsverhouding. Bovendien hanteert ze heel expliciet de termen 'intentioneel' versus 'natuurlijk', twee begrippen die zowel in verbinding als in conflict staan met elkaar. Het 'intentionele' binnen de fenomenologie heeft alles te maken met de constitutie van de objectiviteit vanuit het bewustzijn. Intentionaliteit is de belangrijkste eigenschap van het bewustzijn, maar staat al bij Husserl in een ambigue en problematische relatie tot het levende lichaam ${ }^{11}$ net zoals Malabou dat eigenlijk wil.

De fenomenologische traditie vertoont een verdere ontwikkeling in de richting van naturalisering. Ten eerste heeft Merleau-Ponty het levende lichaam als een constitutief element in zijn fenomenologie opgevat. Hij heeft helder de spanning in Husserls werk tussen een transcendentale analyse van het bewustzijn en de. beschrijvingen van het levende, bezielde lichaam gezien. Het levende lichaam is namelijk een element dat de transcendentale analyse van de intentionaliteit verstoort. Merleau-Ponty heeft dit verstorend element opgenomen als een constructieve factor in zijn eigen analyse van de intentionaliteit. Ten tweede lijken Merleau-Ponty's vroege werken ${ }^{12}$ rechtstreekse suggesties te bevatten voor de naturalisering van de fenomenologie. Zijn werk vertegenwoordigt een ontwikkeling in de fenomenologie die Husserls transcendentale analyse fundamenteel wijzigt en de focus heroriënteert van het transcendentale ego naar het lichaam. Toch neemt ook Merleau-Ponty de paradox van de verwereldlijking van het transcendentale in zijn argumentatie 
mee en schippert hij tussen transcendentalisme en empirisme. Enerzijds wendt hij zich af van het idealistische aspect in de transcendentaalfilosofie. Anderzijds verzet hij zich tegen de naiviteit en het mythologische van het naturalisme of het empirisme. We kunnen ook zeggen dat hij beide probeert in rekening te brengen en uitkomt op een transcendentaal empirisme. Die opzet vinden we expliciet terug in zijn Fenomenologie van de Waarneming (1945): "Het ging ons erom de betrekkingen te begrijpen tussen het bewustzijn en de natuur, tussen het binnen en het buiten. Of anders gezegd, het ging erom het idealistische perspectief, dat stelt dat er alleen iets is als object voor het bewustzijn, te verbinden met het realistische perspectief, volgens welk elk bewustzijn in het weefsel van de objectieve wereld en van de op zich bestaande gebeurtenissen is ingevoegd. Of nog anders ten slotte, het ging erom te begrijpen hoe het kan dat de wereld en de mens voor twee manieren van onderzoek toegankelijk zijn, de een verklarend en de ander reflexief." 13 De gelijkenissen met het project van Malabou zijn treffend. Ook zij balanceert in haar discours tussen enerzijds een waarheid van een reductie tot het materiële, het biologische en het brein, en anderzijds een waarheid van (en oproep tot!) de vrijheid van een actieve, vormende geest die vormgeeft aan de wereld, aan de anderen, maar ook aan de eigen geschiedenis. Voor de filosofen die eerst niet geneigd waren de psychologie te omarmen, geldt hier dat met het afscheid van het transcendentaal idealisme de psychologie haar betekenisvolle, verklarende rol kon herwinnen. Voor de neurowetenschappers (maar ook voor een aantal filosofen) geldt dan weer dat de spanningsvolle verhouding tussen het natuurlijke en het transcendentale de opdracht tot reflectie in zich draagt.

\section{Tot slot: transcendentaal empirisme en verzet}

We zouden kunnen stellen dat Malabou op zoek is naar een transcendentaal empirisme. Merleau-Ponty gebruikt die term niet. We vinden hem wel bij Natalie Depraz (2001), ${ }^{14}$ die het transcendentaal empirisme opvoert als een zeer derridiaanse idee. Een omslag naar een transcendentaal empirisme vindt plaats waar de zuiverheid van een transcendentale analyse wordt geconfronteerd met de onzuiverheden die ze van meet af aan in zich had (het lichaam, het brein, de ander) en waarmee een transcendentale analyse zich ook voedt. In die zin is een transcendentaal empirisme het laatste woord van een husserliaanse fenomenologie. Merleau-Ponty werkt van meet af aan vanuit het perspectief van een transcendentaal empirisme, door precies te vertrekken van het lichaam (of vandaag net zo goed het brein) als een instantie die de twee ordes, deze van de objectiviteit en van de subjectiviteit, doorknuist en in een dialectische spanning brengt. Het moet gezegd dat Malabous specifieke invulling van de spanning transcendentaal-natuurlijk in termen van plasticiteit veel van de filosofische problemen inherent aan zo'n evenwichtsoefening niet aanpakt. Dat was ook haar 
bedoeling niet. Haar project leunt echter bijzonder dicht aan bij het probleem van de naturalisering van de fenomenologie of de verhouding tussen fenomenologie en cognitieve wetenschappen. Dat verklaart ook haar eerder recente verschijnen tussen filosofen als Gallagher, Thompson en Zahavi die al veel langer en ook wel uitgebreider met deze thema's bezig zijn. De verdienste van Malabou ligt dan ook niet in het veld van het lichaam-geestprobleem, waarbinnen haar voorstel zelfs wat flauw kan overkomen.

Er is echter een andere reden om zo veel aandacht aan haar werk te besteden. Haar wel heel bijzondere verdienste is dat ze erin slaagt om de politieke dimensie van dit hoogst theoretische probleem op de agenda te zetten. Of nog, dat ze erin slaagt om de politieke inzetten van zoiets abstracts als het lichaam-geestprobleem op krachtige en overtuigende wijze uiteen te zetten. Haar impliciete boodschap is, dat de filosofie het zich niet langer kan veroorloven om niet politiek te zijn - niet diegenen die nadenken over de mind, en al evenmin de filosofen die werken in de traditie van de fenomenologie, die zich nooit bijzonder veel gelegen liet liggen aan het politieke. Ze roept de filosofie en ook de burgers op tot strategische vormen van geweldloos verzet, tot woede en ook tot hoop.

Wie wil, hoort deze oproep steeds vaker. Een haast identieke oproep tot geweldloos verzet, woede en hoop vinden we recent vanuit heel andere hoek, in het kleine boekje Neem het niet!'s van Stéphane Hessel, dat veel weerklank vond in Frankrijk en het Franssprekende gedeelte van België, maar minder in Vlaanderen. Geweldloos verzet dat strategisch, d.w.z. binnenin het systeem zelf plaatsvindt, is een kenmerk van het post-utopische verzet, waarbij niet langer een volledige afbraak van de heersende orde vanuit een externe positie op de revolutionaire agenda staat, maar eerder kleine ingrepen binnenin het bestaande systeem, op een schaal die iemand zelf kiest en die vaak klein is. ${ }^{16}$ Malabou deed overtuigend haar deel daarin, en toont dat de interpretatie van ons brein in de toekomst een werk is dat van ons allen afhangt - ieder op zijn eigen, zelfgekozen schaal, dus ook die van de abstracte reflectie.

\section{Noten}

1 In het neuraal darwinisme past Gerald Edelman de principes van de populatiegenetica toe op de populatie neuronen in het brein. De verbindingen tussen neuronen zijn onderhevig aan twee soorten selectie. Enerzijds een ontwikkelingsselectie, sterk (epi)genetisch gestuurd, anderzijds een ervaringsselectie, waarbij verbindingen tussen neuronen verloren gaan of versterkt worden op basis van omgevingsstimuli (Zie hiervoor: Edelman G.M., Neural Darwinism. The Theory Of Neuronal Group Selection, New York, Basic Books, 1987. Edelman G.M., Klare lucht, louter vuur, Amsterdam, Bert Bakker, 1993. 
2 Overigens merkt ze in haar nawoord bij de Nederlandse vertaling op dat Gilles Deleuzes anti-kapitalistische analyse ook van zijn kritische potentieel zou ontdaan zijn doordat het is opgenomen in de geest van het huidige kapitalisme.

3 Gezien Malabous ankerpunten is het interessant op te merken dat Changeux' L'homme neuronal (1983) ontstaan is vanuit een onderhoud met Jacques-Alain Miller en diens collega's van het toenmalige tijdschrift Ornicar? en dat Changeux onmiddellijk wijst op Freuds neurologische achtergrond. (Zie hiervoor: Changeux J., L'Homme Neuronal. Parijs, Fayard, 1983.) Op zijn beurt draagt Edelman zijn boek Klare Lucht, Louter Vuur (1993) op aan de twee intellectuele pioniers Darwin en Freud.

4 Damasio A., De vergissing van Descartes - Gevoel, verstand en het menselijk brein, Amsterdam, Wereldbibliotheek, 1998., I $k$ woel dus ik ben - Hoe gevoel en lichaam ons bewustzijn vormen, Amsterdam, Wereldbibliotheek, 1999., Het gelijk van Spinoza Vreugde, verdriet en het voelende brein, Amsterdam, Wereldbibliotheek, 2003., Het zelf wordt zich bewust - Hersenen, bewustzijn, ik, Amsterdam, Wereldbibliotheek, 2010.

5 Het verwondert niet dat Malabou hier verwijst naar Slavoj Žižeks The Parallax View, waarin Žižek onder meer focust op de (cognitieve) neurowetenschappen. (Zie hiervoor: Žižek S., The Parallax View. Ma, MIT, 2006.

6 Roy J.M., 'Beyond the gap : An introduction to naturalizing phenomenology', in: Roy J.M., Petitot J., Pachoud B. \& Varela F. (red.), Naturalizing Phenomenology, Issues in contemporary phenomenology and cognitive science, Stanford, California, Stanford University Press, 1999, pp. 1-2.

7 cf. Husserl E., Ideen zu einer reinen Phänomenologie und phänomenologischen Philosophie, Erstes Buch, Allgemeine Einführung in diereine Phänomenologie. Den Hagg, Martinus Nijhoff, 1950 [1913].

8 Dat betekent niet dat de wereld een creatie is van het bewustzijn, zoals in andere vormen van idealisme. Constitutie en creatie dienen te worden onderscheiden. Constitutie is vooral een kwestie van de actieve totstandbrenging van betekenis. Dit proces van betekenisgeving reikt echter bijzonder ver, en gaat niet enkel uit van een actieve waarneming waarin een wereld tot stand komt, maar sluit aan bij het kantiaanse transcendentalisme waarin op basis van een copernicaanse omwenteling objectiviteit maar mogelijk is onder de voorwaarden van een subjectieve structurering.

9 cf. Husserl E., Ideen zu einer reinen Phänomenologie und phänomenologischen Philosophie, Zweites Buch: Phänomenologische Untersuchungen zur Konstitution. Den Haag: Martinus Nijhoff, 1952.

10 Dodd J., Idealism and corporeity, an essay on the problem of the body in Husserl's phenomenology (Phaenomenologica 140), Dordrecht/ Boston/ London, Kluwer Academic Publishers, 1997, p.80.

11 cf. zijn Ideen II.

12 Merleau-Ponty M., La structure du comportement. Paris, PUF, 2002 [1942]., MerleauPonty M., Fenomenologie van de Waarneming, uit het Fr. vert. d. Douwe T. en Vlasblom R., Amsterdam, Boom, 2009 [1945].

13 Merleau-Ponty M., 2009 [1945], pp. 545-546.

14 Depraz N., Lucidité du corps (Phaenomenologica 160). Dordrecht/ Boston/ London, Kluwer Academic Publishers. 2001.

15 Hessel S., Neem het niet! Amsterdam, Van Gennep, 2011.

16 Bourriaud N., Relational Aesthetics, Dijon, Les Presses du Réel, 2002. 